\title{
PLURALISME HUKUM SEBAGAI MODEL PEMBANGUNAN HUKUM YANG BERKEADILAN
}

\author{
Wandi Subroto \\ Sekolah Tinggi Ilmu Hukum Rahmaniyah, Sekayu \\ Email: wandi.stuhr@gmail.com
}

\begin{abstract}
Abstrak
Adanya perbedaan yang terjadi diantara hukum pidana Indonesia yang bersumber dari hukum kolonial dengan struktur sosial yang ada di Indonesia menunjukkan adanya pluralisme hukum. Secara khusus, Pasal 18 B ayat (2) UUD 1945 menyatakan bahwa negara mengakui dan melindungi masyarakat hukum adat beserta hak-hak historisnya selama masyarakat itu masih ada. Melalui berbagai undang-undang itulah tujuan politik hukum makro, yaitu mengakomodir aturan-aturan baik tertulis maupun tidak tertulis, dilakukan dalam berbagai messo (perantara) politik hukum oleh berbagai undang-undang. Namun, pengakuan terhadap keberadaan hukum adat sebagai salah satu jenis keragaman hukum selama ini sebagian besar diabaikan, seperti yang terlihat dalam kasus Hukum Agraria, misalnya. Oleh karena itu, perlu diakui dan didukung kuatnya pluralisme hukum Indonesia guna mendukung pembangunan hukum.
\end{abstract}

Kata Kunci: Pluralisme Hukum, Hukum Pidana, Hukum Agraria.

\section{Abstract}

Legal diversity is evident in Indonesian criminal law, which is based on colonial law, and the existing social structures in the country. Furthermore, the 1945 Constitution specifies that as long as customary law groups exist, the state respects and preserves them and their historical rights. To accommodate written and unwritten conventions, diverse legal politics messo (intermediaries) implement macro-legal politics through various legislation. According to Agrarian Law, for example, there has been little recognition that customary law exists. The evolution of Indonesian law depends on recognizing and promoting the country's substantial plurality of legal systems.

Keywords: Legal Pluralism, Criminal Law, Agrarian Law.

\section{A. PENDAHULUAN}

Masyarakat Indonesia diatur oleh hukum. Hidup diatur, dikendalikan, dan dibentuk oleh standar dan hukum yang berusaha menghasilkan ketertiban dan keadilan bagi semua. Menurut Philippe Nonet \& Philippe Selznick (2003), ada tiga jenis hukum: represif, otonom dan responsif. Menurut Philippe Nonet \& Philippe Selznick hukum yang baik seharusnya menawarkan sesuatu yang lebih daripada sekedar keadilan prosedural. Untuk menanggapi keinginan/tujuan hukum masyarakat, maka diciptakanlah hukum progresif. Karena sifatnya yang progresif, hukum progresif ini diyakini sebagai hukum terbaik untuk menjamin keadilan masyarakat. Mereka harus dilaksanakan oleh semua faktor pembentuk hukum, termasuk norma, penegakan, dan masyarakat (Rahardjo, 2000).

Konteks hal tersebut di atas tidak lepas dari situasi yang ada pada masa Orde Baru, ketika negara dipimpin oleh presiden, yang dengan bebas menggunakan haknya untuk melakukan pencopotan dan penyangkalan dalam format hukum melalui penafsirannya 
terhadap UUD. Penggunaan kekerasan dalam penafsiran hukum diperlukan untuk mempertahankan kekuasaan pada saat itu. Politik hukum merupakan strategi mempertahankan kekuasaan yang juga dapat digunakan sebagai alat untuk meredam perlawanan kekuatan politik yang tidak sesuai dengan tujuan kebijakan Orde Baru. (Simarmata, 2005).

Ketidakadilan akan terjadi akibat adanya penyeragaman (unifikasi hukum) hukum dalam budaya yang heterogen/beraneka ragam, seperti di Indonesia yang terdapat sebanyak 550 suku bangsa. Sebagai contoh, Undang-Undang Nomor 5 Tahun 1960 tentang Pokok-pokok Pokok Agraria, yang secara jelas mengatur bahwa hukum adat itu meliputi tanah, air, dan udara tetapi telah diselewengkan oleh negara, telah dirusak oleh pemerintah. Sama tidak adilnya dengan menerapkan berbagai hukum (pluralisme hukum) kepada sekelompok orang yang hidup dalam masyarakat yang sama. Indonesia yang menyandang semboyan negara yang terkenal "Bhinneka Tunggal Ika" memiliki beraneka ragam suku, ras, kepercayaan, peradaban, dan sebagainya, namun Indonesia, terlepas dari keragamannya, merupakan satu kesatuan yang tidak dapat dibagi-bagi (Sumardi, 2016).

Gejala pluralisme dapat dilihat pada sistem hukum negara yang kaya akan pluralisme. Sebagai respon terhadap hukum negara yang ketat dan statis, masyarakat telah melakukan tindakan dan cara tersebut. Hanya memenuhi aspirasi hukum dari mereka yang berbagi adalah tujuan di sini; itu hanya sebuah usaha. Ini adalah visi ideal masyarakat tentang supremasi hukum. Sistem pemerintahan yang terpusat tidak dapat mencapai tujuan ini karena banyaknya ragam suku, bahasa, dan budaya yang telah dikaruniai Tuhan Yang Maha Esa kepada kita, adalah hal yang mustahil (Hariyanto, 2020).

Reformasi hukum pidana Indonesia yang berupaya menggabungkan hukum yang ada saat ini ke dalam isi peraturan hukum pidana, merupakan bentuk politik kriminal dalam mengkriminalisasi perilaku. Upaya ini bersifat anti kriminal dan pro kesejahteraan, karena kondusifitas dalam kehidupan sosial masyarakat merupakan salah satu variabel yang berkontribusi terhadap terciptanya kesejahteraan masyarakat (Nugroho, 2019). Pluralisme hukum merupakan keuntungan tetapi juga kerugian karena, jika tidak dimasukkan ke dalam undang-undang, dapat berkontribusi pada ketidakefektifan hukum dengan membuatnya tidak sesuai dengan budaya masyarakat atau dengan mengisyaratkan bahwa masyarakat tidak menginginkan hukum yang bertentangan dengan masyarakat (Irianto, 2017).

Selama anggota masyarakat itu masih hidup dan bertindak menurut kepentingannya sendiri dan peraturan perundang-undangan yang mengatur Negara Kesatuan Republik Indonesia, negara mengakui dan melindungi masyarakat hukum adat dan hak-hak tradisionalnya berdasarkan Pasal 18 B ayat (2 ). Mengingat Rencana Pembangunan Jangka Panjang Nasional 2005-2025, penting untuk menyadari pentingnya pluralitas hukum yang kuat dalam pertumbuhan hukum Indonesia untuk mendorong pembangunan hukum di Indonesia. Undang-Undang Dasar Negara Republik Indonesia Tahun 1945 Pancasila dan perkembangan muatan hukum, baik hukum tertulis maupun hukum tidak tertulis, mempertimbangkan banyak rezim hukum, baik hukum maupun tidak tertulis.

Latar belakang inilah yang memicu rasa ingin tahu penulis untuk mendalami kajian normatif filsafat hukum secara lebih mendalam. Ada sejumlah komponen yang melingkupi filsafat ilmiah yang dapat dikaji dari segi teleologi, ontologi, epistemologi, dan aksiologi untuk memverifikasi dan membuktikan keberadaannya. Dengan asumsi bahwa pluralisme hukum adalah tempat lahirnya keadilan sosial bagi bangsa Indonesia, maka postulat/proposisi awal ini 
didasarkan pada asumsi tersebut. Oleh karena itu, masalah utama yang harus ditangani adalah apakah pluralisme hukum merupakan strategi yang efektif untuk mendorong pertumbuhan yang adil dalam sistem hukum atau tidak.

\section{B. METODE}

Sebagai studi hukum normatif, penelitian ini mengkaji norma-norma dalam hukum positif dengan menggunakan studi pustaka. Menurut Diantha (2016), Normative Legal Research (NLR) adalah penelitian yang berfokus pada isu-isu terkait pluralisme hukum sebagai paradigma evolusi hukum yang berkeadilan. Metode yang digunakan dalam penelitian ini adalah metode konseptual, yaitu gagasan untuk merevisi hukum pidana Indonesia.

\section{HASIL DAN PEMBAHASAN}

\section{Pluralisme Hukum di Indonesia}

Sejak awal abad kedua puluh, para ilmuwan telah tertarik pada pluralisme hukum, namun definisi kata mereka sangat bervariasi di antara para antropolog, sosiolog, sarjana hukum, dan ilmuwan politik. Namun, mayoritas ulama menggunakan skala deskriptif mulai dari pluralisme hukum 'miskin' hingga 'kuat'. Dengan tidak adanya pluralisme hukum, penguasa membentuk badan hukum yang berbeda untuk segmen masyarakat yang berbeda (Pradhani, 2021). Pluralisme hukum dicirikan dalam hal ini sebagai kerangka hukum di mana pengelompokan penduduk yang berbeda didefinisikan menurut etnis, agama, atau afiliasi lainnya. Pluralisme hukum seringkali tidak dibenarkan sebagai pendekatan pemerintah dalam masyarakat seperti itu dengan alasan pragmatis. Hal ini juga sering diamati sebagai suatu kondisi yang ditentukan oleh koeksistensi dua atau lebih interaksi hukum yang sekarang menjalani proyek modernisasi negara-bangsa. Pluralisme hukum yang 'lemah' ini sering dikritik karena terlalu bergantung pada negara dan karena ciri-ciri penting hubungan antara entitas non-negara dan lingkungan sosial semi-otonom (Dewi, 2014).

Jenis pluralisme hukum ini adalah di mana tidak semua undang-undang dibuat oleh pemerintah atau dilaksanakan melalui lembaga-lembaga negara. Melainkan menggambarkan koeksistensi berbagai tatanan hukum yang tidak termasuk dalam satu sistem dalam konteks sosial (Irianto, 2017). Bersama-sama, mereka tidak serta merta mengakui atau mengecualikan keberadaan satu sama lain. Fokus pada interaksi antara hukum resmi dan tidak resmi dalam pembicaraan tentang pluralisme hukum yang kuat telah beralih dari melihat pengaruh hukum terhadap masyarakat atau sebaliknya (Yastiko, 2022). Menurut pakar pluralisme hukum, terdapat oposisi biner lain yang membedakan antara pluralisme hukum yang "lemah" dan "kuat", seperti: klasik vs baru, awal/akhir, yuridis/sosiologis, dan pluralisme hukum vs. hukum yang mendalam. kemajemukan.

Peninggalan kolonial tentang pluralitas hukum tetap dijalankan oleh Indonesia pascakemerdekaan, meskipun dengan penyesuaian-penyesuaian tertentu. Untuk menjaga persatuan Indonesia dan integritas peradilan, lembaga hukum adat (peradilan desa) terutama dihilangkan pada 1950-an. Namun, pengadilan distrik terus menegakkan aturan adat. Pada saat yang sama, sistem peradilan agama di Indonesia menerapkan beberapa aspek hukum Islam. Dengan demikian, Indonesia telah menciptakan sistem pluralisme hukum yang rumit, yang memungkinkan berbagai subsistem hukum berfungsi di bawah lingkup satu sumber kekuatan negara yang berdaulat (Atmaja, 2012). Modernisasi hukum di Indonesia merupakan proses 
yang menekankan sentralisme hukum dan positivisme hukum, namun sistem hukum yang plural ini dibangun di atas kebijakan hukum Indonesia yang bertujuan untuk mendorong modernisasi hukum. Peraturan perundang-undangan nasional Indonesia menunjukkan dikotomi ini seperti halnya organisasi hukum formal. Contoh nyata bagaimana kebijakan Indonesia yang mengacu pada sentralisme hukum justru telah melahirkan pluralisme hukum adalah UU Pokok Agraria dan UU Perkawinan.

Ketika Indonesia mengadopsi gagasan yang dikenal sebagai 'diferensiasi hukum' di awal 1990-an, kebijakan hukum di negara ini berubah secara radikal. Kelompok warga negara tertentu diberikan undang-undang khusus yang hanya berlaku untuk mereka, sedangkan kelompok lain ditolak undang-undang tersebut (Salim \& Azra 2003). Oleh karena itu, Indonesia didorong untuk melanjutkan pengembangan sistem hukum internasional yang membedakan orang berdasarkan latar belakang agamanya, membuka pintu bagi pluralisme hukum yang lebih besar di negara ini.

Sebagaimana telah dikemukakan sebelumnya, TAP MPR No. IX/MPR/2001 pasal 4/c menyatakan bahwa: "Menghormati supremasi hukum dengan menerima keragaman dalam kerangka kesatuan hukum”. Ada dua cara yang digunakan pluralisme hukum dalam praktiknya: pertama, sebagai media/lingkungan untuk menciptakan dan memelihara aturan-aturan baik yang sudah ada maupun yang baru yang merespon perkembangan-perkembangan tersebut. Kedua, sebagai alat untuk membuat aturan baru. Untuk melindungi dan mempertahankan keyakinan dan cita-cita masyarakat dari campur tangan nilai dan norma eksternal yang tidak sesuai, dengan menegaskan bahwa aturan ada di masyarakat yang bersangkutan. Aturan yang dipengaruhi dan dibantu oleh nilai-nilai dari luar komunitas sangat penting untuk efektivitasnya. sebagai stimulan agar sistem sosial direvitalisasi dan bekerja dengan baik; dan ketiga, Untuk mencapai keadilan bagi mereka yang kekurangan sumber daya untuk membela komunitasnya, para penyelenggara gerakan sosial telah menggunakan pluralisme hukum, yang merupakan alat yang ampuh.

Tidak ada hukum pertanahan yang jelas di Indonesia sampai pemerintah Soekarno mengesahkan Undang-Undang Nomor 5 Tahun 1960, yang memperjelas hak negara atas tanah melalui gagasan "Hak Penguasaan oleh Negara" yang memberikan penguasaan eksklusif kepada negara atas tanah. Dengan kata lain: Pranoto, (2017) menjelaskan Hak ulayat ini sudah lama dimiliki oleh kelompok hukum adat, tetapi telah dihapuskan karena kekuasaan negara yang total. Sebagai akibat dari populasi budaya Indonesia yang besar dan beragam, negara telah mengakui bahwa hukum yang mengatur kehidupan masyarakat sehari-hari dipengaruhi oleh berbagai sumber, termasuk lembaga negara dan masyarakat hukum adat. Dalam perumusan undang-undang, negara membutuhkan strategi yang berfokus pada penjangkauan masyarakat daripada penegakan hukum negara. Mengingat hal ini, pentingnya mengadopsi pendekatan pluralistik untuk merancang undang-undang nasional digarisbawahi.

\section{Pluralisme Hukum sebagai Model Pembangunan Hukum yang Berkeadilan}

Dengan demikian, menurut UUD Indonesia, Hukum dan Aparatur Negara mempunyai mekanisme untuk membangun hukum nasional yang sejalan dengan Pancasila dan UndangUndang Dasar Negara Republik Indonesia Tahun 1945, dengan tetap memperhatikan berbagai pengaturan hukum yang berlaku. Sebagai teks ketatanegaraan, UUD 1945 (termasuk Pembukaan) menjadi landasan bagi politik hukum di tingkat nasional. 
Melalui berbagai undang-undang itulah tujuan politik hukum makro, yaitu mengakomodir aturan-aturan baik tertulis maupun tidak tertulis, dilakukan dalam berbagai messo (perantara) politik hukum oleh berbagai undang-undang. Hukum mikro politik diimplementasikan oleh berbagai peraturan perundang-undangan yang bahkan lebih subordinat dalam penerapannya. Akibatnya, suatu peraturan perundang-undangan (hukum nasional) akan diundangkan, dan akan didasarkan pada prinsip-prinsip yang telah ditetapkan pada tataran politik hukum makro (Soepiadhy, 2010).

Dengan tanah nasional berdasarkan hukum adat, kesulitan muncul dalam situasi di mana sikap/sudut pandang hukum tanah nasional diungkapkan dalam bentuk peraturan perundang-undangan semaksimal mungkin. Dasar hukum pertanahan nasional tidak bertentangan dengan peraturan perundang-undangan jika memperhatikan salah satu standar hukum adat yang telah diterapkan. Dapat dikatakan bahwa hukum adat menempati tempat yang lebih rendah daripada norma-norma formal dalam masyarakat. Apabila suatu ketentuan hukum adat terbukti bertentangan dengan hukum, ketentuan hukum adat tersebut dinyatakan tidak berlaku.

Jika kita mengikuti prinsip yang terkenal dalam hukum antar-kelompok, "prinsip persamaan", yang menyatakan bahwa semua hukum memiliki nilai yang sama dan diperlakukan dengan cara yang sama, kita dapat menyimpulkan bahwa ini adalah pelanggaran hukum yang tidak sah. Sebagai hasil dari konsep ini, semua sistem hukum diberikan jumlah nilai atau derajat yang sama (hukum adat serta peraturan perundang-undangan). peraturan perundang-undangan tidak dapat dilaksanakan/tidak dapat dilaksanakan/hukum adat tidak berlaku, sedangkan hukum adat tidak dapat dilaksanakan/peraturan perundang-undangan tidak dilaksanakan, dan sebaliknya (Atmaja, 2012).

Oleh karena itu, dalam hal terjadi perbedaan pendapat antara hukum adat dan norma perundang-undangan, maka hukum adat yang ditimpa tidak dapat dibenarkan dengan asas persamaan, dan hukum adat yang ditimpa tidak dapat dibenarkan dengan asas lain. Dengan demikian, hukum adat yang masih hidup dalam masyarakat (living law) dan peraturan perundang-undangan berada pada pijakan yang sama atau sederajat, dan tidak ada yang dapat dimanfaatkan untuk membawa yang lain menjadi batu sandungan (Mujib, 2014).

Seperti yang terjadi pada masa pemerintahan Hindia Belanda, kedua undang-undang tersebut dibiarkan hidup secara bersamaan (dualisme hukum pertanahan). Di Hindia Belanda terjadi dualisme hukum pertanahan, yang berarti masyarakat harus hidup dengan dua perangkat hukum tanah, satu berdasarkan hukum adat dan satu berdasarkan hukum barat. Meskipun pemerintah Hindia Belanda mengklaim bahwa semua tanah selain yang tunduk pada hak eigendom adalah milik negara, tanah adat tetap tunduk pada hukum negara di mana mereka berada.

Hukum dipelajari dari perspektif antropologi sebagai aspek yang melekat pada struktur dan fungsi budaya secara keseluruhan. Akibatnya, hukum dari sudut antropologis tidak hanya berbentuk peraturan perundang-undangan yang dibentuk oleh negara (state law), tetapi juga berbentuk peraturan daerah yang bersumber dari hukum adat (hukum adat/folk law), serta mengatur mekanisme di dalam masyarakat. Ini adalah bentuk pengaturan diri yang juga berfungsi sebagai alat kontrol sosial (ketertiban hukum) (Gadacz, 1987).

Secara umum, pluralisme hukum dianggap sebagai komponen yang melemahkan ambiguitas, barang resmi negara, mengganggu tatanan institusi formal dalam topik tertentu, 
dan yang paling parah, merusak 'aturan hukum'. Jika dibandingkan dengan pluralisme, hukum sering dikritik karena efektivitasnya dalam mengendalikan hubungan sosial, tetapi hukum negara dianggap lebih mampu daripada menganggap semua pihak sebagai titik pertemuan semua perbedaan pendapat, menurut pandangan ini. Sementara itu, pluralisme hukum dipandang sebagai sumber kesulitan dalam mengembangkan aturan-aturan yang menguasai wilayah-wilayah tertentu, khususnya di kalangan pembuat kebijakan, karena seringkali bertentangan dengan kepentingan otoritas politik, baik yang duduk di parlemen maupun yang menjabat di pemerintahan. Terutama ketika undang-undang negara bagian sedang dibuat dan ketika masyarakat lokal tidak berpartisipasi secara partisipatif, komunitas lokal semakin terpinggirkan.

Masyarakat adat, di sisi lain, memiliki bentuk legalisasi sendiri yang mereka gunakan di komunitas mereka sendiri. Setelah pemerintah memberikan Hak Pengusahaan Hutan, Hak Pengusahaan Industri, Hak Pengusahaan Industri, dan hak-hak lain yang masuk dan menduduki wilayah tanah adat, perjuangan legalisasi mau tidak mau semakin memburuk.

Menurut Irianto (2017), masalah pluralitas hukum ada dalam dua dimensi di Indonesia, yaitu:

a. Kompleksitas pluralisme hukum baik dalam sistem hukum negara maupun sistem hukum rakyat digali dalam tulisan ini. Dalam kehidupan sehari-hari, kita selalu dapat menemukan sistem hukum selain hukum negara, seperti hukum adat, agama, perjanjian adat, dan konvensi sosial lainnya yang telah diserap sebagai "hukum" oleh masyarakat dan telah menjadi bagian dari budaya masyarakat. Dengan demikian, hukum negara tidak berfungsi sebagai monopoli atau sebagai acuan eksklusif untuk mengatur hubungan sosial warga negara dalam kehidupan sehari-hari.

b. Warga negara dapat menanggapi aturan hukum dengan cara yang berbeda tergantung pada pengetahuan, minat dan terutama budaya mereka. Masalah pluralisme hukum tidak hanya pada keberadaan keragaman hukum tetapi juga pada individu yang tunduk pada lebih dari sistem hukum. Karena setiap orang memiliki pengetahuan, harapan dan kepentingan (sosial, politik, ekonomi) atau lebih tepatnya budaya hukum yang berbeda.

\section{KESIMPULAN}

Kehidupan manusia tidak bisa dilepaskan dari hukum. Hukum dalm hal ini tidak hanay dipandang sebagai penjaga ketertiban dan keamanan serta ketentraman akan tetapi lebih penting hukum adalah untuk menciptakan rasa keadilan, kepastian dan kemanfaatan bagi setiap manusia. Sebagai hasil sebuah pemikiran hukum di tuntut untuk bisa dinamis dan selalu dapat menyesuaikan dengan perkembangan zaman supaya dapat memenuhi apa yang menjadi citacita masyarakat tentang keadilan hukum yang substansif. Pluralisme hukum adalah istilah yang mengacu pada keragaman dan heterogenitas masyarakat, serta kondisi kehidupan yang berubah sebagai akibat dari globalisasi. Pluralisme hukum adalah keadaan yang memungkinkan masyarakat untuk menunjukkan pilihan hukum yang sesuai dengan prinsip keadilan dan bermanfaat bagi masyarakat.

Eksistensi pluralisme hukum telah diakui dalam hukum negara melalui keberadaan Pasal 18B ayat (2) UUD 1945 namun dalam substansi hukumnya, pengakuan negara terhadap keragaman hukum misalnya dalam hukum pertanahan masih lemah (weak legal plluralism). pluralisme hukum. yang hidup dalam keseharian masyarakat karena menyadari bahwa 
Indonesia memiliki banyak sekali keragaman budaya. Untuk mengembalikan pengakuan pluralisme hukum sebagai model pembangunan negara hukum yang berkeadilan, negara harus memiliki strategi dalam pembangunan hukum melalui negara yang menekankan pada pengenalan hukum kepada masyarakat daripada memaksakan penegakannya dari hukum negara. Pendekatan pluralisme hukum dalam pembentukan hukum nasional menjadi sangat penting.

\section{DAFTAR PUSTAKA}

Atmaja, G. (2012). Politik Pluralisme Hukum dalam Pengakuan Kesatuan Masyarakat Hukum Adat dengan Peraturan Daerah (Doctoral dissertation, Universitas Brawijaya).

Dewi, A. A. I. A. A. (2014). Eksistensi Otonomi Desa Pakraman dalam Perspektif Pluralisme Hukum. Jurnal Magister Hukum Udayana, 3(3), 44135.

Diantha, I. M. P. (2016). Metodologi Penelitian Hukum Normatif Dalam Justifikasi Teori Hukum. Prenada Media.

Gadacz, R. R. (1987). Folk Law and Legal Pluralism: Issues and Directions in the Anthropology of Law in Modernizing Societies. Legal Stud. F., 11, 125.

Hariyanto, H. (2020). Hubungan Kewenangan antara Pemerintah Pusat dan Pemerintah Daerah Berdasarkan Negara Kesatuan Republik Indonesia. Volksgeist: Jurnal Ilmu Hukum Dan Konstitusi, 3(2), 99-115.

Irianto, S. (2017). Sejarah Dan Perkembangan Pemikiran Pluralisme Hukum Dan Konsekuensi Metodologisnya. Jurnal Hukum \& Pembangunan, 33(4), 485-502.

Mujib, M. M. (2014). Memahami Pluralisme Hukum di Tengah Tradisi Unifikasi Hukum: Studi atas Mekanisme Perceraian Adat. Supremasi Hukum: Jurnal Kajian Ilmu Hukum, 3(1).

Nonet, P., \& Selznick, P. (2003). Hukum Responsif: Pilihan di Masa Transisi. Perkumpulan untuk Pembaharuan Hukum Berbasis Masyarakat dan Ekologis (HuMa).

Nugroho, N. (2019). Urgensi Pembaruan Kitab Undang-undang Hukum Pidana dalam Dinamika Masyarakat Indonesia. Jurnal Spektrum Hukum, 14(1), 39-57.

Pradhani, S. I. (2021). Pendekatan Pluralisme Hukum dalam Studi Hukum Adat: Interaksi Hukum Adat dengan Hukum Nasional dan Internasional. Undang: Jurnal Hukum, 4(1), 81-124.

Pranoto, C. B. (2017). Pembangunan Negara, Hukum Pertanahan Indonesia, Dan Kembalinya Tanah Kasultanan di Yogyakarta. Jurnal Politik, 3(1), 21-51.

Rahardjo, S. (2000). Ilmu hukum. Citra Aditya Bakti.

Salim, A., \& Azra, A. (2003). Negara dan Syariat dalam Perspektif Politik Hukum Indonesia. dalam Burhanuddin (ed.), Syariat Islam Pandangan Muslim Liberal, Jakarta.

Simarmata, R. (2005). Mencari Ciri-Ciri Pluralisme Hukum, dalam Landasan Hukum, Pluralisme Hukum Suatu Pendekatan Interdisipliner. Jakarta: FF Huma.

Soepiadhy, S. (2012). Bekerjanya Hukum dalam Masyarakat. Surabaya: Surabaya Pagi.

Sumardi, D. (2016). Islam, Pluralisme Hukum dan Refleksi Masyarakat Homogen. AsySyir'ah: Jurnal Ilmu Syari'ah dan Hukum, 50(2), 481-504. 
Undang-Undang Nomor 17 Tahun 2007 tentang Rencana Pembangunan Jangka Panjang Nasional 2005-2025.

Undang-Undang Nomor 5 Tahun 1960 tentang Pokok-pokok Pokok Agraria.

Yastiko, R. (2022). Pluralisme Hukum Dalam Pandangan Antropologi Hukum Para Ahli. 